\title{
Biskop Jørgen Hansen
}

\section{ET FOREDRAG.}

\section{Af M. Mackeprang}

Offentligg $\varnothing$ relsen af dette Foredrag skyldes udelukkende Ønsker udefra, der er bleven tiltraadt af Redaktionen. Selv havde jeg ikke tænkt herpaa, da det jo ikke bringer noget nyt, men næsten helt bygger paa den gamle Biskops, i Sønderj. Aarb. for 1904 trykte Erindringer. For $\operatorname{dog}$ i nogen Maade at raade Bod herpaa har jeg tilf $\varnothing j$ et en Redeg $\varnothing$ relse for Oprettelsen af hans Bisped $\varnothing \mathrm{mme}$ (S. 2 f.), ligesom der S, 14 er indskudt et lille Stykke til nærmere Forklaring om hans Stilling til Problemet »Slesvigs Deling . Derimod har jeg med Vilje og velberaad $\mathrm{Hu}$ bibeholdt Foredragets Ord og Tone.

Om selve sErindringerne kan jeg forøvrigt nu oplyse, at de foreligger i to Redaktioner, hvortil Manuskripterne findes paa Det kgl. Bibliotek (Ny kgl. Samling. 1624, 2a) begge skrevne med hans. egen letkendelige Haandskrift. Det ene og sikkert det ældste (I), hvor Skriften er noget større og kraftigere, blev i 1910 skænket Biblioteket af hans S $\not n$, Herredsfoged Hansen, og er senere bleven forenet med II, der efter en Paaskrift paa sidste Side er afsluttet August 1883.1) Det er dette sidste, der ligger til Grund for Udgaven i S $\varnothing$ nderj. Aarbøger, og det gengiver sikkert Erindringerne i den Form, han selv $\phi$ nskede dem offentliggjort. Thi at han har syslet med denne Tanke, fremgaar klart af et Brev fra Herredsfogeden (1909 18/11) til nu afdøde Arkivar Axel Hejls, der ligger sammen med Manuskripterne. Det maa dog bemærkes, at der $i$ dette (II) er foretaget en Del Strygninger, antagelig af hans anden S $\emptyset$ n, Oberst J $\phi$ rgen Hansen, fra hvem Aarbøgernes Redaktion, der intet anede om I's Eksistens, i sin Tid modtog Manuskriptet, og, som jo ogsaa som anført i Aarbøgerne (S. 201, Anm.) har suppleret - og vist delvis mildnet - Afsnittet vedrørende Striden om hans Pension. Betegnende for Karakteren af hans Udeladelser er Udeladelsen af en Side (Bl, 307-08), hvor Bispen fortæller om den pinlige

1) I synes at være nedskrevet mellem 1878 og 1880. Hvad Fakta angaar, ender det med Skildringen af hans Guldbryllup i $1878 \mathrm{og}$ omtaler ikke hans Deltagelse i Provinssynoden 1880. (Jfr. S. Aarb. 1904. S. 209 og 204). 
Situation, han kom i, da han ved den officielle Festmiddag efter hans Præstejubilæum (Udg. S. 203) maatte udbringe Kejserens Skaal, og giver et Uddrag af sin Tale.

Den ældste Redaktion virker $\mathrm{i}$ det hele noget bredere, medtager f. Eks. flere Smaatræk, der ikke findes i II. Og selvom de to Redaktioner stort set dækker hinanden, er der dog paa flere Punkter ret betydelige Afvigelser. Saaledes findes de Betragtninger, han anstiller i Anledning af sit Cirkulære til Præsterne (Udg. S. 165-74), kun i II, men er i I erstattet med en Udvikling af hans Hensigt med Cirkulæret. Det skulde dels afværge en Masseafskedigelse af Præsterne, dels give dem en Vejledning med Hensyn til Forholdene under Occupationen. Til Gengæld har han i II udeladt saavel en Afskrift af den i Udg. S. 2n2-03 omtalte Erklæring, om hvorfor han ikke vilde modtage Regeringens Anmodning om at lade sig opstille ved det første Landdagsvalg, som en Karakteristik af de første tyske Landraader i S $\varnothing$ nderborg og den ovenfor nævnte Tale for Kejseren. Da de to sidste Udeladelser ikke er uden Interesse, Talen, der jo i grunme ringe Grad beskæftiger sig med Kejseren, giver saaledes et godt Billede af Bispens Indstilling overfor Tidens politiske Frihedsbestræbelser og Nationalitets$1 \phi$ ret, er de aftrykte som Tillæg, Talen er dog oversat paa dansk, men med Bevaring af Bispens ofte noget afstumpede Sætninger.

Naar jeg som Foredragsæmne paa vort Aarsmøde i Broager valgte at tale om gamle Biskop Jørgen Hansen i Guderup, var det baade fordi han var en ejendommelig, særpræget og selvstændig Personlighed, og i national og politisk Henseende en udmærket Repræsentant for en helt uddød Retning, som navnlig "Ungdommen“ nuomstunder vist har svært ved at forstaa. Men desuden en Mand, der i sin Tid havde en ikke ringe Betydning netop for Als og Sundeved, lad saa være, at han vel nu er glemt af de fleste.

Inden jeg gaar over til ham, vil det dog være rimeligt at fortælle lidt om det besynderlige Bispedømme, han styrede fra 1848 til 64. Det var saa rart overkommeligt, omfattede kun Als med Undtagelse af Sønderborg og Kejnæs Sogn samt Erø. Ialt talte det kun 18 Sogne, hvorfor Bispen tillige var Sogne- 
præst i Egen) og ogsaa fungerede som Amtsprovst. Ligesom Femern, der indtil 1864 statsretslig var en Del af Hertugdømmet Slesvig, laa disse Øer i Middelalderen under Odense Stift. Noget efter Reformationen gled Femern ud, men for de to andre Øer paanær Sønderborg og det først 1614 oprettede Kejnæs Sogn, der hørte under Slesvig Stift, bevaredes deres gamle Forbindelse med Fyen. Dette havde den praktiske Betydning, at her, som i Tørninglen, gjaldt ikke den særlig slesvigske, men den kongerigske Kirke- og Skolelovgivning. Vedrørende disse Forhold hørte Øerne ikke under Tyske (slesvig-holstenske) Kancelli, men under Danske Kancelli. Og dette ændredes ikke ved Oprettelsen af Bispedømmet i 1819 eller efter Treaarskrigen, hvor Øernes øverste kirkelige Myndighed ikke var det da oprettede Ministerium for Slesvig, men Danske Kancellis delvise Arvtager, Kultusministeriet.

At de to Øer administrativt henhørte under to Kollegier, medførte naturligvis en Del Besvær og Ekstraskriverier, lad saa være, at det er noget overdrevent, naar den tillige som en Slags Provincialregering fungerende Overret paa Gottorp betegnede Forholdet som „en Kilde til stadige Kollisioner og Tvedragt“. Ligefra 1803 førtes der da ogsaa Forhandlinger om en Findring, og en Tid lang synes man at have fundet en Løsning $i$ en Plan, der gik ud paa, at Als i kirkelig Henseende blev indlemmet i Slesvig Stift, medens Ærø til Gengæld helt blev lagt til Kongeriget. Planen blev tiltraadt af to Odensebisper (Bloch og P. Hansen), men stødte paa Modstand baade hos deres Efterfølger Fr. Plum (1813-34) og den constituerede Amtsprovst, Pastor Ebbesen i Svendstrup. Deres Hovedindvending var Frygten for at faa Præster og Lærere, der ikke kunde tilstrækkelig Dansk. Thi medens de alsiske Præster hidtil gennemgaaende var bleven uddannede i København, vilde den paatænkte $\mathrm{Ny}$ ordning medføre, at de for Fremtiden gik til Kiel, ved hvis

2) Præstegaarden ligger i Guderup, hvorfor han regelmæssig omtales som Biskop H. i Guderup. 
Universitet alle, der søgte Præstekald i Slesvig Stift, efter en 1768 udstedt Forordning s k u ld e studere i to Aar, det saakaldte biennium. Ogsaa Hertugen af Augustenborg var imod Planen, som han mente vilde kunne skade hans Patronatsret til de syv af Sønderherreds otte Kirker..)

Trods de mange og lange Forhandlinger svnes det hele dog at være løbet ud i Sandet. Under 9. April 1819 resolverede Kongen nemlig, at den hidtidige Ordning skulde vedblive indtil videre, dog saaledes at der efter Forslag af Danske Kancelli skulde nedsættes en Kommission til at overveje, hvorledes der kunde indfores større Frihed med Hensyn til Lovgivning og Administration. ${ }^{4}$ )

Hvorvidt der kom noget ud heraf, skal lades usagt, men samme Dag faldt der en anden kgl. Resolution, om Oprettelsen af Bispedømmet Als og \#rø. ${ }^{5}$ ) Strængt taget behøver disse to Sager jo intet at have med hinanden at gøre, men det ligger dog nær, at der maa have været en vis Forbindelse mellem dem, saameget mere som de nævnes jævnsides $i$ en, en halv Snes Dage senere afsendt Skrivelse til Fyens Guvernør Prins Christian Frederik, den senere Christian VIII.") I en i Gehejmestatsraadets Indstilling optaget Erklæring fra Danske Kancelli om Bispedømmets Oprettelse, der vist ikke helt har været efter dets Hoved, hedder det, at et saa lille Bispedømme ganske vist er usædvanligt. Men, fortsættes der, skulde „Hensigten“, som ikke nærmere defineres, naaes, vil det dog være nødvendigt, at den nye Biskop, i Lighed med hvad der skete, da Lol-

3) Ovenstaaende bygger paa en Erklæring af 1817 12/9 fra Overretten paa Gottorp til Tyske Kancelli, der nu ligger i Indlæg Nr. 128, til Danske Kancelli's 1. Depts. Registrant for 1819: - Ganske karakteristisk siger Overretten om Bispens Hovedindvending, at den $*$ vil fylde enhver Forstandig og Upartisk med Uviljex. - Om Bienniet jfr. Slesvigs delte Bisped $\varnothing$ mme. S. 188.

4) Danske Kancellis 1. Depts. Forestillingsprotok. 1819, Nr. 75.

b) Som ovenfor. Nr. 74.

6) En Afskrift af denne Skrivelse af 21. April ligger i det i Anm. 3 nævnte Indlæg Nr. 128. 
land-Falster 1803 udskiltes fra Odense Stift, ${ }^{7}$ ) ogsaa overtog de Pligter, der paahvilede Amtsprovsten. Thi - og nu kommer "Hensigten" aabenbart for Dagen - herved vilde det opnaaes, at Hertugen af Augustenborg med Hensyn til Kirke-og Skolesager ikke fik baade med Fyens Biskop og tillige med en Amtsprovst at gøre, men alene med en Biskop, „hvorimod han ikke synes at have noget at erindre". Noget Aktstykke, hvorpaa Kancelliet stotter denne Formodning, har jeg ikke kunnet finde, men det turde være givet, at det er Hensynet til den da ganske unge Hertug Christian August, der har været af afgørende Betydning. Man har aabenbart villet vise Hs. Durchlautighed den Honnør at fritage ham for at forhandle med en saa forholdsvis underordnet Embedsmand som en Amtsprovst; en Biskop kunde bedre gaa. For at forstaa dette maa man huske, at Hertugen ikke blot var Frederik VI's Søstersøn, men ogsaa Tronfølgerens Svoger, idet Prins Christian Frederik 1815 havde ægtet hans Søster Caroline Amalie. Og som Guvernør paa Fyen $k$ a $n$ Prinsen jo underhaanden have haft en Finger med $i$ Spillet.

Men fra Stiftet tilbage til Manden. Han var født $\mathbf{i}$ Tandslet :802. Der var Faderen Smed, men han tilhorte en paa Sundeved vidt udbredt Storbondeslægt, var saaledes Fætter til H. P. Hanssens Fader, gamle Christen Hanssen paa Nørremølle. Hvis Bispen efter god, gammel Bondesæd er bleven opkaldt efter sin Farfader, var denne Sandemand i Nybøl Herred. Med Rette kunde han derfor om sig selv have brugt de Ord, med hvilke H. P. Hanssen indleder sine Erindringer: „Min Slægt har dybe Rødder i Sønderjylland." Og som vi skal se, prægede dette ogsaa hans hele Tankesæt.

Som Dreng gik han naturligvis i Tandslet Skole, men dette var ham ikke nok. Af en fransk Læsebog, der tilfældig var

7) Til Sammenligning mellem de to Stifters Størrelsesforhold skal nævnes, at Lolland-Falster Stift omfattede 99, Als og झrø kun 18 Sogne. 
strandet hos hans Fader, søgte han at lære sig selv Fransk, og en Tid lang læste han ogsaa om Aftenen Tysk med Degnen. Navnlig var han dog - og vedblev at være - stiv i Regning, og det var dette, der ved en Visitats henledte Bispens Opmærksomhed paa ham. Det gav Anledning til, at han fra nu af blev undervist af Præsten, der i Forvejen havde fire-fem Elever. Ikke saa faa Præstegaarde hernede var jo paa den Tid hele smaa Latinskoler. ${ }^{8}$ ) I 1819 blev han saa Student i København og valgte snart sagt selvfølgelig at studere Theologi.') Baade da og langt senere var Præstekjolen jo det store Maal for Smaakaarsbørn, der gik den studerte Vej. Jeg tror dog ikke, at jeg gaar den gamle Biskops \#re for nær, naar jeg mener, han egentlig burde have været Jurist. Et klart og skarpt Hoved havde han og viste sig senere som en fremragende Administrator.

I Tidens almindelige Studenterliv tog han kun ringe Del, holdt sig næsten helt til jævnaldrende Landsmænd. Og heller ikke Hovedstadens rige aandelige Liv, som det udfoldede sig i Litteraturen og paa Theatret, synes at have fængslet ham. Altfor fedt sad han naturligvis ikke i det, men jeg er dog ikke sikker paa, om de Ord ikke ogsaa passer paa ham, som en gammel Præst lod falde, da jeg udtalte min Glæde over at sidde $i$ et Præstekontor, hvis Vægge bogstavelig talt var tapetseret med Bøger: „Mine unge Kolleger siger, at de har ikke Raad, men jeg tror nu, det er noget andet!"“

Vi er saa vant til at betragte Alsingerne som særlig lyrisk betonede. Tænk blot paa Forfatteren til Als' Nationalsang „Af Østerhavets Vove“, Kristen Karstensen, der indtil 64 var Provst her i Broager. Han var født i Ulkebøl. Eller for at gaa ned til vore Dage: Christen Ernst Christensen, Peter Grau og Folke-

8) Jfr. Hejselbjerg Paulsen i slesvigs delte Bispedømmer. S. $169 \mathrm{f}$.

9) Naar H. P. Hanssen i sin Nekrolog over J. H. i Sønderj. Aarb. 1890 siger S. 22, at det først var hans Agt sat studere Philologi , skyldes dette en Forveksling mellem Embedsexamen og den saakaldte sanden Examen*, som alle Studenter dengang skulde tage, og hvor de klassiske Sprog spillede en stor Rolle. 
maalsdigteren Martin N. Hansen. Men dette gælder saavist ikke Jørgen Hansen. Selv indrømmer han aabent og ærligt i sine Erindringer, at han ganske mangler Sans for alt, „hvad der henhører under Estetikken," ligesom han aldrig har kunnet "bekvemme" sig til at læse en Roman, hverken de dengang saa yndede Walter Scott'ske eller Ingemanns Kongebøger. (S. 30). Det falder da ogsaa godt i Traad hermed, at Pastor Carsten Petersen i sin mærkelige Bog "Slesvigske Præster" fortæller (S. 132-33), at der ikke $i$ hans Bibliotek fandtes en eneste skønlitterær Bog. Hvad han søgte i sin Læsning - og han blev efterhaanden en meget belæst Mand, velbevandret i den klassiske Oldtids Litteratur og i Religionshistorie - var Fakta og atter Fakta, og det lader sig da heller ikke nægte, at hans Erindringer ofte er en noget tor Kost.

I 1823 fik han en fin theologisk Examen og blev nogle Aar senere Huslærer hos Pastor Schwensen i Hørup, hvis Søn, den sidste danske Præst sammesteds, han skulde forberede til Studenterexamen. Her fandt han sin Brud i en af Præstedøtrene og kom saaledes ind $i$ den stærkt sammengiftede Kreds af "Proprietærer" og Præster, der var saa karakteristisk for Als baade dengang og snart sagt Aarhundredet ud: Knudsenerne paa Lysholm, Jessenerne paa Majbølgaard, Witzkerne paa Hjortholm, Schwensenerne og Fanglerne.

I 1827 blev han Præst Vesterude i Ballum. Foruden af sin egentlige Præstegerning var han stærkt optaget af Skole- og Fattigvæsenet, Omraader hvor Præsterne dengang havde meget at sige, og for hvilke han stadig bevarede en levende Interesse. Hvorledes var han nu som Præst? Hans religiøse Indstilling maa vist nærmest karakteriseres som en rationalistisk-farvet Højkirkelighed; her som i sin politiske Virken var han "Manden i Midten". Pietismen saavelsom Grundtvigianismen stod ham fjærnt, og efter Carsten Petersen ejede han ikke én Bog af Søren Kierkegaard. Men han var en tolerant Mand, hvad han fik Lejlighed til at vise overfor den første Retning. 
Takket være Indflydelsen fra Christiansfeld var der nemlig en Del Pietisme i Sognet. Men, siger han i sine Erindringer (S. 53), „jeg gik ud fra, at saalænge de ikke gjorde sig skyldige i lovstridige Handlinger, vedkom det ikke mig, hvad de tænkte“. En tiltalende Modsætning til den Forfølgelse af de gudelige Forsamlinger, der dengang ikke var saa helt ualmindelig. Som Prædikant tog han sin gamle Lærer Pastor Sabro i Tandslet som Forbillede. Efter hvad han fortæller (S. 28-29), hævdede denne, at de bedste Prædikener var dem, som Folk troede, at de ligesaa godt selv kunde have holdt, hvorfor hans egne da ogsaa var "simple, fattelige og practiske for Livet“. Maaske har Jørgen Hansen dog drevet det lidt for vidt i denne Retning. I en forøvrigt meget anerkendende Nekrolog i Illustr. Tidende (30. Bd. Nr. 49) siger Forfatteren, at han ikke var nogen god Taler, og karakteriserer hans Prædikener som „væsentlig Moralprædikener“. Men alligevel var hans Kirke altid fuld.

I og for sig trivedes han godt derovre Vesterpaa, hvor han fik bragt Orden i Sognets forvirrede Fattigvæsen. Men Familien vilde have ham hjem, og allerede 1830 blev han derfor Præst i Notmark. Han var bleven kaldet dertil af Hertug Christian August af Augustenborg, der havde Patronatsret til alle Kirkerne i Sønderherred, paa nær Kejnæs, og kom derved i nærmere Berøring med denne omstridte Mand, „æ Herzog“, som han almindeligt kaldtes i mine Drengeaar, da Mindet om ham endnu var levende. Selvom Hertugen ikke direkte blandede sig i de kirkelige Forhold, var Konflikter med ham vanskelige at undgaa. Thi, som Jørgen Hansen fortæller (S. 57), „det Første han forlangte af Enhver, der skyldte ham en Stilling, var at deele hans Anskuelser om de fyrstelige Rettigheder", han mente at have, altsaa baade sin Arveret til Hertugdømmerne, naar Kongehusets Mandslinje var uddøet, og sine Særrettigheder som Godsejer i stor Stil. Men paa begge disse Omraader fik han snart en skarp Modstander i den Notmark Præst.

Da Christian Paulsen i Tredverne ved sine Skrifter aabnede 
Kampen mod Slesvigholsteinismen, traadte Jørgen Hansen i Forbindelse med ham. Han fik da at vide, at man i Haderslev tænkte paa at starte en dansk Avis, der baade skulde kæmpe for Slesvigs Danskhed og dets statsretslige Forbindelse med Danmark, og her vilde man gærne have ham med. Hertil var han da ogsaa villig. Han stod da allerede forlængst i Opposition til Hertugen, og ikke mindst var hans Uvilje bleven vakt ved dennes Machinationer for at skubbe den af Bønderne ved det første Valg til Stænderforsamlingen i Slesvig 1834 udkaarede dansksindede Gaardejer Christian Bonefeldt til Side for sin Kandidat, Herredsfoged Steffens. $\mathrm{Nu}$ blev han en af de første Bidragydere til "Dannevirke“. Hvad der bragte ham frem paa Arenaen, var et i Stænderforsamlingen stillet Forslag om Indforelse af fire ugentlige tyske Timer i de nordslesvigske Folkeskoler. Det var tænkt som et Modtræk mod Nis Lorenzens Forslag om Genindførelse af dansk Retssprog i Nordslesvig, men $i$ et meget sagligt og grundigt Indlæg, der strakte sig over hele fire Numre af "Dannevirke“ - en Afhandling kalder han det da ogsaa selv - paaviste Jørgen Hansen imidlertid, at disse fire tvungne Timer ikke blot var skadelige for den ellers helt danske Folkeskole, men ogsaa til ingen Verdens Nytte for Børnene. Han traadte ogsaa $i$ personlig Forbindelse med "Dannevirke"s Redaktør, Peter Christian Koch, hvem han lovede flere Bidrag, og sendte ham bl. a. en Artikel om "Nutidens Politik“. Den vilde have givet os et Billede af hans egen Opfattelse af dette Spørgsmaal, men desværre kendes den ikke, da det paagældende Nummer blev beslaglagt af Politimesteren i Flensborg, hvor Bladet dengang tryktes, uagtet Herredsfoged v. Wimpfen i et Brev til Flor betegnede den som "ganske loyal". ${ }^{10}$ ) Trods alle Eftersogninger i Arkiver og Biblioteker har det suspekte Nr. ikke været til at finde ${ }^{11}$ ), men en Erstatning faar vi dog gen-

19) P. Lauridsen, Da Sønderjylland vaagnede. I, 203.

11) Jfr. Sønderj. Aarb. 1930. S. 273. Heller ikke i $\gg$ K $\varnothing$ benhavnsposten «, hvor Wimpfen $\mathrm{i}$ det nysnævnte Brev til Flor raader denne til at faa den optaget, synes den at have fundet Husly. 
nem de af Pastor H. F. Petersen i Sønderj. Aarbøger 1930 aftrykte Breve fra Jørgen Hansen til Koch, der giver et klart Indblik $i$ hans nationale og politiske Indstilling. J et af disse ( $\mathrm{S}$. 263 f.) fortæller han saaledes om en tysk Artikel, der i Oversættelse var bleven optaget i "Sønderborg Ugeblad“,12) og afskriver det Svar, han havde ment det nødvendigt at give. Bl. a. havde Forfatteren (Herredsfoged Steffens i Nordborg? jfr. S. 268) paastaaet, at hvis den nordslesvigske Befolkning fik Valget mellem, om den vilde være rent dansk eller rent tysk, vilde ikke én af Hundrede vælge at være dansk. „Der er Godt og Ondt i alle Lande, og vi ønsker helst at blive, hvad vi ere“, skriver Jørgen Hansen. „Men skulde vi endeligen have Valget, da vilde vel næppe mange Bønder betænke dem, og den gode Mand kund tage feil." Med denne Udtalelse bør dog sammenholdes et Tillæg, han $i$ et andet Brev til Koch foreslaar til sin Artikel om „Nutidens Politik“: „Skulde Nogen i denne . . . ville finde den saameget omtalte Tendents til Hertugdømmernes Adskillelse, da maa jeg derimod udtrykkeligen protestere" (S. 272). De to Citater viser, at han ikke blot var dansk Slesviger, men ogsaa dansk Helstatsmand, der ikke vilde opgive Forbindelsen med Holsten, men opretholde Monarkiet i dets gamle Omfang, hvor Grænsen ikke var Ejderen men Elben. For at forstaa dette maa man jo huske, at selv om Holsten hørte til det tyske Forbund, og Slesvig statsretslig var dansk og dengang overvejende dansktalende, var det snart sagt i alle Livets dagligdags Forhold nærmere knyttet til Holsten end til Kongeriget. For at begynde med Toppen, styredes de to Hertugdømmer gennem det slesvig-holstenske Kancelli. De havde fælles Toldgrænse ved Kongeaaen, og skulde man hernede betale sin Købmandsregning, var det ikke i Rigsbankdaler og -skilling, men i Kurantdaler og hamborgske (opr. lybske) Skilling. Ligeledes var Skattegrundlaget et andet. I Kongeriget Hartkorn, i Hertugdømmerne det middelalderlige Plovtal. Intet Under, at man endnu i Be-

12) Dette findes ikke i københavnske Biblioteker. 
gyndelsen af forrige Aarhundrede om Slesvig kunde bruge Benævnelsen „Dansk-Holsten“.

Det Standpunkt, Jørgen Hansen indtog i Tredverne, beholdt han til 1864. Det viser sig klart i hans saa ofte fremdragne Udtalelse fra 1848, da han i de bevægede Martsdage oplevede Ejderstatens Proklamation paa Casinomødet: „De Folk er gale. Det er en ligesaa stor Separatisme som den anden“, altsaa den slesvigholstenske (S. 139). En lille Snes Aar senere siger han $i$ en Skrivelse til de tyske Kommissærer, der 1864 styrede Slesvig, „at det havde fyldt hans Hjerte med Sorg, at Danske og Tyske ikke kunde leve fredelig sammen i en dansk-tysk Stat" (S. 179). Og, hedder det videre sammesteds, „Dansk er mit Modersmaal, Tysk delvis mit Familiesprog". For os virker dette sidste overraskende, men anderledes var det dengang. Indtil Treaarskrigens Afslutning taltes der saaledes altid tysk til Børnene i A. D. Jørgensens Hjem i Graasten, hvor dog, som han siger i sine Erindringer (S. 16 og 17), „Sundveds danskhed i disse forvirrede år havde en af sine hovedrødder". Hvorfor Bispens Hussprog delvis vedblev at være tysk, skal jeg lade være usagt. Det kan sikkert ikke skyldes Smedesønnen fra Tandslet, hvis Uddannelse jo i Modsætning til de fleste andre slesvigske Præsters, var helt dansk. Snarest skyldes det vel Præstedatteren fra Hørup, hvor man ellers var dansksindet nok, men Tysk var nu engang det fineste. Det være nu hermed, hvad det vil. Dansk var han, og det vedblev han at være selv i det kvart Aarhundrede, han efter 1864 sad som Præst i den tyske Statskirke. Men ganske vist var hans Danskhed af en anden Art end den, der besjælede Frederik Fischer i Aabenraa, om hvem en af hans tyske Modstandere erklærede, at hvis Domsbasunen paa den yderste Dag ikke blæser dansk, staar han ikke op af Graven. Endsige da "Dannevirkes" saa iltre og lyrisk betonede Redaktør, der aabenbart havde noget vanskeligt ved at acceptere Jørgen Hansens Helstatsindstilling og - hvad man unægtelig kan forstaa - ved at forsone sig med hans lang- 
strakte, tungt læselige Artikler. Det synes, som han holdt nogle af dem tilbage, hvad Chr. Paulsen mildt bebrejder ham, og i et Brev til Flor (1840 17/6) siger han rentud, „Hansen ... tor vi ikke opfordre til at skrive, da han er alt for detail, kjeder og mangler al poetisk Aand. Han snakker Folk i Serv". Et Aars Tid senere, da "Dannevirke“ var vokset i Omfang, anslaar han vel mildere Toner: „Efterat Bladet er blevet saa udvidet og udgaar saa hyppig, er en saadan Medarbejder vor rette Mand“, men tilføjer forsigtig "uden at vi dog derfor ville tilskynde ham til Vidtløftighed"! (P. Lauridsen. IV, 71, 131 og 203). Baade tidligere og senere bevarede Jørgen Hansen da ogsaa Forbindelsen med Bladet, og endnu i 1843 sendte han det „adskillige gode Ting" (P. Lauridsen. VI, 22). Hvor forskelligt de to Mænd saa paa det rent sproglige Spørgsmaal Dansk og Tysk, fremgaar bedst af deres Indtilling overfor det danske Seminarium, flere havde tænkt paa $i$ al Stilhed at faa oprettet i Nordslesvig. Hansen havde sendt Bladet en Artikel herom, men da han i denne havde anset det for nodvendigt, at det af Hensyn til det ovenfor omtalte Forslag om de fire tyske Timer ogsaa fik tyske Lærere, karakteriserede Koch det som „en Tvetulle“, „Det skulde være rent Dansk, ellers ingen“. Ja, i et Brev til sin Mentor Flor, hvori han beder om Undskyldning, fordi han ikke havde sendt ham Artiklen til Gennemsyn, gaar han endogsaa saa vidt som til at udtale: „Iøvrigt er det min Mening, at faaer Pastor Hansen ... Lov til at raade for den Sag, saa Farvel med Danskheden i Nordslesvig“ (P. Lauridsen I, 221-22). Naa, Koch var jo, som alt sagt, et iltert Hoved, hvis Ord ikke skal tages altfor bogstavelig, og at Jørgen Hansen ingenlunde havde svigtet sit Modersmaal, viser et Par Artikler, han nogen Tid efter skrev. I en af dem imødegik han den gamle tyske Skrøne om, at vort gode sønderjydske Maal ikke er dansk: "Taler man her [o: i Slesvig] ikke dansk, taler man ikke tysk i Holsten", siger han med Rette og gaar stærkt i Breschen for Reskriptet af 1840, der havde paabudt dansk Rets- og Admini- 
strationssprog i Nordslesvig. Det var en simpel Retfærdighedshandling mod Befolkningen, til hvis Sprog Øvrigheden hidtil ikke havde taget Hensyn. Men vel at mærke fremkom saavel disse som andre Indlæg fra 1840 ikke i "Dannevirke“, men i en tysk Avis, nemlig det dengang endnu ret neutrale "Kieler Correspondentzblatt" (jfr. Erindringer. S. 74-75). Den mest træffende Karakteristik af ham giver sikkert P. Lauridsen i sit prægtige Værk „Da Sønderjylland vaagnede“ (I, 66): „Stiv, gammeldagstænkende og rationalistisk bundede han langt dybere i det daværende slesvigske Liv end Flor og hans Mænd. Han var dem en trofast Støtte i Gennembruddets Dage, men senere formaaede han ikke at vinde med $i$ det stærke Aandsog Frihedsliv, der bar Udviklingen".

Det var dog ikke blot Hertugens antidanske og statsopløsende Politik, der bød ham imod. Ogsaa hans hensynsløse og junkeragtige Adfærd mod Bønderne paa hans talrige Godser bragte hans Bondeblod i Kog. Thi han glemte aldrig „den Stand, jeg af Naturen syntes bestemt til at skulle tilhøre" (S. 97). Den kunde give sig Udslag i direkte Uretfærdigheder, som f. Eks. ved Hoveriafløsninger, i smaalige Chikanerier, som naar han nægtede de Bønder, der ikke havde stemt paa hans Kandidat (Steffens) til Stænderforsamlingen, Adgang til at faa deres Hopper bedækket paa hans Stutteri paa Augustenborg. ${ }^{13}$ ) Men ikke mindst viste den sig i den Maade, hvorpaa han udøvede sin Jagtret. Jeg husker endnu fra fordums Tider min gamle Ven Jørgen Iversen i Svejrups Harme over de hertugelige Jagter, og det var sikkert ikke helt galt, naar Jørgen Hansen i 1838 spaaede "Dannevirke" større Udbredelse paa Als og Sundeved, „især om De ikke vil spare Jagten“ (Sønderj. Aarb. 1930. S. 271).

Men - Hertugen var nu en Gang hans Patron, alt blev rapporteret til ham, og med Rette eller Urette ansaa han det derfor nødvendigt at gaa lidt sagte med Dorene. Da „Danne-

13) Jfr. om dette sidste Hertugens Brev af 1834 26/10 i »Danske politiske Breve fra 1830erne og 1840erne«. I, 56. 
virke" begyndte at udkomme, turde han saaledes ikke selv tegne sig som Abonnent, men fik en venligsindet Nabopræst til at holde Bladet. Selvfølgelig var man dog paa Augustenborg klar over, hvor han stod, og det føltes derfor som en stor Lettelse, da Christian VIII, der vidste, at han gerne vilde bort fra det hertugelige Distrikt, 1845 udnævnte ham til Præst i Egen, der var et kongeligt Kald.

Snart skulde han dog naa højere op paa Rangstigen. Kongen var klar over, at Biskoppen paa Als havde en farlig Stilling. $\mathrm{Da}$ den gamle Biskop Tetens ønskede at tage Afsked, og Kongen "vilde have en Mand, han kunde stole paa“ (S. 81), blev Jørgen Hansen derfor hans Efterfølger i Febr. 1948.

Hans Udnævnelsesbrev ender med den Passus, at han „skal finde sig i de Forandringer, som det muligen maatte behage os (o: Kongen) at befale foretaget med bemeldte Bispedømme" (S. 85). Der sigtes her til den af Christian VIII paatænkte Deling af Slesvig i to Generalsuperintendenturer efter Kirke- og Skolesproget, altsaa et for Sydslesvig og et for Nordslesvig, i hvilket Als og \#rø da naturligvis maatte indgaa. ${ }^{14}$ ) Det fremgaar af hele Sammenhængen, at det er herpaa, der tænkes, naar den senere Stiftsskriver, daværende Redaktør for „Nationaltidende“ H. R. Hiort-Lorenzen i sin Nekrolog over Jørgen Hansen, som han personlig maa have staaet nær - han kalder ham sin gamle Ven - fortæller, at han var tidlig stemt for Slesvigs Deling. ${ }^{15}$ ) Det er altsaa noget andet, end naar H. P. Hanssen i sine Erindringer (II, 39) skriver, at efter Hertugdømmernes Indlemmelse i Prøjsen "havde han sluttet sig til Delingstanken". Vi ved ikke, hvorledes han tidligere havde stillet sig til en saadan statsretslig Deling, en Tanke, der jo allerede 1 1848 var fremme baade fra dansk og tysk Side. Men efter hele hans Indstilling overfor Hertugdømmernes Forhold saavel ind-

14) Jfr. Slesvigs delte Bispedømme. S. 350 f. 39.

15) Journalistforeningens Kalender Danmark*. 1890. S. 29. Jfr. tillige en Nekrolog af Th. H. (Theodor Hindenburg?) i Illustr. Tidende, 30. Bd. Nr. 49: 'Tanken om Slesvigs Deling var ham ikke fremmed. 
byrdes som til Kongeriget, forekommer det mig lidet sandsynligt, at han har delt den. Selve den administrative Deling af Slesvig i to Stifter blev forøvrigt gennemført af Slesvigholstenerne og i nogle Aar opretholdt af den danske Regering, idet Provst Jep Hansen i Jordkær og den loyale Præst Asschenfeldt afløste de af den provisoriske Regering indsatte Provst Rehhoff og N. Nielsen. Først 1854 udnævntes Provsten U. S. Boesen i Fjelstrup til Biskop - ikke Superintendent - over hele det gamle Slesvig Stift, altsaa med Undtagelse af Als, Erø cg Tørninglen. ${ }^{10}$ )

Ligesaa tilfreds Øens danske Befolkning var med sin nye Biskop - alle Bønderne $i$ hans gamle Sogn kom saaledes over for at onske ham tillykke - ligesaa forbitret var man paa slesvigholstensk Side. Paa Augustenborg, hvor man betragtede ham som Sjælen i den danske Opposition, "rasede" man, og hans tysksindede Efterfølger i Notmark Fr. Petersen skrev senere, at hans eneste Fortjeneste bestod i, ,at han personlig var en retskaffen Mand og tillige en fanatisk Dansker, men manglede ellers helt kirkeligt Sindelag og al kirkelig Begavelse“. ${ }^{17}$ ) Hvor stor Tillid, Regeringen havde til ham, viste sig, da den først udnævnte ham til Medlem af den "Immediatkommission“, der efter Vaabenstilstanden i Malmo skulde styre Hertugdømmerne, og da den paa Grund af tysk Sabotage ikke kunde træde i Virksomhed, til Medlem af en lignende Bestyrelseskommission for Als og Ærø, der under hele Krigen var besat af danske Tropper. I over et Aar havde han sammen med den loyale Amtmand Johannsen fra Haderslev - i nogle Maaneder ogsaa alene - den øverste civile Styrelse af Øen, hvilket ikke løb af uden Rivninger med de militære Myndigheder.

16) Slesvigs delte Bispedømme. S. 358.

17) Fr. Petersen. Erlebnisse eines schleswig'schen Predigers. 1856. S. 130. - Om dennes Skæbne i de bevægede Aar 1848-49, for hvilken Biskoppen g $\emptyset \mathbf{r}$ udf $\varnothing$ rlig Rede, har Aage Dahl givet en kort Oversigt i S. Aarb. 1929, S. 145 f.. Her skal blot tilføjes, at han ved sine ondsindede Beretninger var en af de fordrevne tyske Præster, der bidrog mest til at lægge Danmark for Had. 
Rent militært havde Danmark sejret i Treaarskrigen, men i politisk Henseende havde man ikke naaet det Maal, man først havde sat sig: Danmark til Ejderen. Tværtimod hade man ved de saakaldte Aftaler af 1851-52 med Projsen og Østrig maattet forpligte sig til ikke at knytte Slesvig nærmere til Kongeriget, end Holsten blev det. Tiden mellem Krigene sled sig derfor hen med Forsøg paa at skabe en Fællesforfatning, der kunde holde Monarkiet samlet, indtil man endelig brød overtvært og paa det for os uheldigst mulige Tidspunkt i 1863 gennemforte Novemberforfatningen, der helt udelukkede Holsten. Det blev Christian IX's meget tunge Pligt faa Dage efter sin Tronbestigelse at underskrive denne Forfatning, som blev den direkte Anledning til Krigen 1864. Men tillige havde man ved de saakaldte Sprogreskripter af 1850 og 51 nationalt søgt at vinde, hvad der af Mellem- og Sydslesvig endnu var dansktalende - og lidt til endda. Efter dem blev Skolesproget dansk i 48 Landsogne-dog med 4 ugentlige tyske Timer - Kirkesproget afvekslede dansk og tysk, mediens der gaves frit Valg mellem de to Sprog ved Domstolene og i den verdslige Administration.

Hvorledes stillede Bispen i Guderup sig nu til alt dette? Allerførst Sprogreskripterne, der jævnsides med det storpolitiske var Tyskernes Hovedangrebspunkt. De var tænkt som en Gennemførelse af Frederik VI's desværre aldrig udførte Reskript af 1810, der paabød, at Dansk skulde være Kirke-, Skole- og Retssprog, hvor det var „Allemands Sprog“. Dengang havde det vel nok kunnet gennemføres med Held, nu efter Fyrrernes Nationalitetskamp og en blodig Krig var det forsent. Tysk var nu engang „die heilige Sprache“, og selv i loyale eller rent dansktalende Sogne stødte de paa Befolkningens Modstand eller i bedste Fald Ligegyldighed. Mod dem havde Bispen dog i Modsætning til en anden konservativ Dansk-Slesviger, Angelboen, Biskop Martensen, intet at bemærke, men bifaldt dem helt. „Jeg forstaaer ikke, hvor der i Tyskland derover kunde hæves et 
Ramaskrig", siger han i sine Erindringer (S. 43) og minder spottende om, hvorledes Prøjserne gik frem mod det danske Sprog i Nordslesvig i Skole og paa Tinge. Hele den politiske Udvikling tiltalte ham derimod ikke, for at bruge et mildt Udtryk. At han var en erklæret Modstander af Ejderpolitiken, er alt sagt, men ligesaa utilfreds var han med de forskellige Fællesforfatninger. Ved Valget til Rigsraadet for Monarkiet i 1855 brændte han saaledes sin Stemmeseddel! Præsterne skulde overhovedet jkke give sig af med Politik, for ikke at vække Splid i deres IMenigheder. Og paa mange af de unge danske Embedsmænd, der kom herned, saa han med nogen Skepsis. Vel var de allerfleste dygtige og retsindige Mænd, men de kendte intet til Folk og Forhold hernede, følte sig for meget som Missionærer og Befriere (S. 146). Ja enkeltvis kunde de optræde taktløst og dumt, som naar en af dem ved en Fest for det danske MindretaliȘtænderforsamlingen udtalte: „Man taler om slesvigske Eiendommeligheder, jeg kjender ikke Andet end slesvigske Jammerligheder" (S. 150). Overfor Slesvigholstenerne onskede han Fred og Forsoning, og Rejsningen af Flensborgløven betragtede han som et "Misgreb“ (S. 152). Det var han nu ikke ene om. Ikke blot den konservative Helstatsmand, Overpræsident v. Rosen i Flensborg, men ogsaa en saa fuldgod Nationalliberal som Johs. Helms, Forfatteren til "Jeg elsker de grønne Lunde“, der som Frivillig havde deltaget i Treaarskrigen, syntes ikke om den. $\left.{ }^{18}\right)$ Hans Ønskedrøm var en Tilstand som før Nationalitetskampens Begyndelse i Tredverne, og der er noget tragisk $i$, at den ellers saa kloge og forstandige Mand ikke kunde eller vilde indse, at man ikke kan dreje Historiens Hjul tilbage, allermindst da ikke, naar der som her var flydt saa meget Blod.

Saa kom 1864. Meget mod sin Vilje blev Bispen paa selve Dybbøldagen valgt som Medlem af det ved Novemberforfatningen skabte Rigsraads Landting. Han mødte da ogsaa $i$

${ }^{18)}$ Jfr. Sprogforeningens Almanak. 1947. S. 65-66. 
København, men faa Dage efter erobrede Prøjserne Als, og efter Aftale med Premierministeren rejste han derfor hjem, hvor han troede at kunne gøre mere Nytte end i Kobenhavn. Over det endnu ikke besatte Kejnæs naaede han da ogsaa lykkelig til Guderup og udsendte omgaaende et Cirkulære (S. 165 f) til Stiftets Præster, der for at bruge hans egne Ord (S. 168) "har været underkastet megen forskjellig Bedømmelse“. Forøvrigt i Overensstemmelse med den danske Regering opfordrede han dem nemlig til at blive paa deres Plads, tage de deraf følgende Konsekvenser og adlyde den bestaaende Magt. I sine Erindringer drøfter han indgaaende, hvad der kan siges for og imod denne Holdning. Han indrømmer, at ikke mindst under de daværende Forhold vil det for mange være et meget tungt Offer. Men, fortsætter han, derfor er det ikke mindre hæderligt at bringe dette Offer end at overlade Fjenden Pladsen. Og det saa meget mere, som hvis der er nogen, „der af Embedsmandens Bortgang har Fordeel, saa er det Fjenden, der derved i Regelen erholder Leilighed til at anbringe en Mand, der bedre virker i hans Aand" (S. 171). Hans Indflydelse var da ogsaa saa stor, at da der 1867 krævedes, at Embedsmændene skulde aflægge Troskabsed til Kongen af Prøjsen, var der kun tre af Als' Præster, der vægrede sig ved at aflægge Eden. ${ }^{19}$ ) Der kan da heller næppe være Tvivl om, at hans Indstilling overfor dette Spørgsmaal - han opfattede Eden som en simpel Lydighedserklæring - var Grunden til, at saa yderlig faa af de gamle danske Lærere i Aabenraa og Sønderborg Amt nægtede at aflægge Eden. Og hvad dette betød for Børnene, vil man kunne faa et indtryk af ved i $H$. P. Hanssens Erindringer (I, $66 \mathrm{ff}$ ) at læse om hans Skolegang i Snogbæk, hvor de Skarns Unger fulgte Lærerens Eksempel og rev „Schleswig-Holstein meerumschlungen" ud af den paabudte tyske Læsebog og gladelig sang danske Fædrelandssange $\mathrm{i}$ den sidste Skoletime, hvor de var sikre paa ikke at faa Besøg „af høje Herrer". Anderledes

14) S’nderjyllands Historie. V, 45. 
var det jo Nord- og Vesterpaa. Dér fulgte man Krügers Parole og saa just ikke med blide Øjne paa de Lærere, der havde aflagt Eden. „Egentlig danske Mænd, endskøndt de nok begge har aflagt Eden", hedder det $i$ et samtidigt Brev om et Par af dem. ${ }^{20}$ ) Der var kortsagt det samme Skel i det daglige Liv som i den store Politik, hvor vore Landdagsmænd en Tid lang endogsaa efter Krügers Død nægtede at aflægge Ed paa den prøjsiske Forfatning og derved udelukkede sig selv fra at indtage deres Pladser i Landdagen. Ret tidlig rejste der sig imidlertid Protest herimod, ikke blot paa Als og Sundeved, men ogsaa i Haderslev Østeramt, medens Vesteramtet var Ednægternes faste Borg. Denne Meningsforskel kom ogsaa til at gribe ind i Bispens Liv.

Krigen havde faktisk ophævet hans Bispedømme, idet Erø vedblev at være dansk, og de tyske Civilkommissærer, der foreløbig styrede Hertugdømmet, havde derfor afskediget ham som Biskop over Als og givet ham Valget mellem at vedblive at være Præst i Egen eller nedlægge sin Stilling som Biskop over \#rø. Herom førtes der mange og lange Forhandlinger, men endnu længere og bitrere var den Strid, han havde med den danske Regering om sin Bispepension for Ærøs Vedkommende. Efter 10 Aars Forløb syntes den endelig at faa en for ham gunstig Løsning ikke mindst takket være en Henvendelse fra Ahlmann, der stærkt fremhævede den Betydning, han havde haft for Danskheden baade før og efter 64. Den strandede dog paa en Protest fra Haderslev Vesteramt, der endog gik saa vidt, at den erklærede, at en Imødekommen af hans Krav vilde blive følt som et Slag i Ansigtet paa Krüger. Man naaede derfor kun en halv Løsning, med hvilken han slog sig til Ro.

Selv fortsatte han sin Gærning som Sognepræst i Egen til $\sin$ Død d. 16. Aug. 1889, højt elsket og æret af sin Menighed. Han havde nu forsonet sig med Tanken om Slesvigs nationale Deling og udtalte sig med megen Skarphed om det prøjsiske Sty-

20) Min $»$ Nordslesvig $1864-1909 \ll$. S. 58. 
re, da hans unge Slægtning H. P. Hanssen engang besøgte ham (Et Tilbageblik. II. 38-39). Men noget af den samme Dobbelthed, der havde præget ham $i$ fordums Tider, var der stadig over ham. Regeringen var ganske klar over, hvad han betød for Stemningen paa Als, og opfordrede ham til at stille sig som Kandidat ved det første Landdagsvalg i 1867. Dette afslog han selvfølgelig, hvorimod han ikke mente at kunne sige Nej til den prøjsiske Orden, der blev tilbudt ham ved hans 50-aarige Præstejubilæum 1877, selvom han, som han spottende skrev - og ogsaa sagde $i$ sin som Tillæg aftrykte Takketale ved den officielle Middag - ikke kunde indse, at han havde gjort sig særlig fortjent af Prøjsen (S. 203). Og af hans to Sønner blev den ene, Jørgen H., dansk Officer, den anden Chr. H. 1868 Herredsfoged o) Dommer og Politimester i Nybøl Hrd. med Bolig i Broager uden dog at opgive sit danske Sindelag.

Ja selv ved hans Jordefærd, der havde samlet et mægtigt Følge, vedvarede denne Dualisme. For forste og sidste Gang mødtes her Gustav Johannsen, Redaktor Jessen og H. P. Hanssen med den gamle Landraad v. Tschirschnitz og Sønderborgs tyske Kommandant. „Et Afsnit af Sonderjyllands Historie fandt med dette Dødsfald sin Afslutning", skriver H. P. Hanssen med Rette i sine Erindringer (II, 40).

At hans Landsmænd tilslut forstod ham, hvad enten de nu hørte til Protest- eller Forhandlingsfolkene, for at bruge de gamle Slagord, fremgaar noksom af, at „Flensborg Avis“ aftrykte „Dybbøl-Posten"s meget lange, sikkert af H. P. Hanssen skrevne Nekrolog. ${ }^{21}$ ) Mere kneb det i Kongeriget. Jeg mindes endnu tydelig, hvorledes jeg engang som ung Lærer maatte bryde en Landse for den gamle Biskops Ere med min Skolebestyrerinde, der beskyldte ham for at være en arg Tysker.

M. Mackeprang.

21) Ogsaa Hiort-Lorenzen bifalder i $\sin$ S. 14 Anm. 16 anførte Nekrolog ganske hans Holdning efter 1864 . 


\section{TILL $Æ G$}

A.

Redaktion I. S. 297—99, der slutter sig til Udg. S. 203. Forud for det gaar en Afskrift af den sammesteds nævnte Indberetning.

.... Landraad Matthiesen var en født Flensborger og oprindelig loyal dansk, men hørte til de mange, som den danske Regjering ved sit ukloge Forhold havde stødt fra sig, og som derfor 1848 var reven med af Strommen, og nogle Aar senere havde erholdt Ansættelse i Pommern, men 1864 med saa mange andre var kommen tilbage. Som preussisk Embedsmand holdt han og maatte han holde over den preussiske Autoritet, men han opdagede dog snart, ligesom v. Zedlitz, at de gamle Slesvigholstenere ikke alle vare Dydsmønstre. En Tidlang varetog han sit Kald uden at blive forulempet, men da v. Bitter var bleven Regjeringspræsident, ${ }^{28}$ ) skulde dansk Sprog og Alt, hvad dansk var, med Magt udryddes, og da Landraad Matthiesen ikke vilde lade sig bruge til Alt, kun vilde haandhæve Loven, maatte han soge sin Afsked, ${ }^{23}$ ) som han erholdt med Pension. Han erfarede ved denne Leilighed, at de, som han havde troet sine Venner, vare ham langt farligere end de, som han holdt for sine Fjender. Blandt dem, med hvilke v. Bitter havde lang Forhandling, var den for Logn og Uredelighed af Overtribunalet i Berlin senere ligefrem afsatte Amtsdommer Boisen paa Nordborg. Landraad Matthiesen lever i Kiel, har Pension og flere communale Hverv, samt viser megen Interesse for den herværende Befolkning, har ogsaa viist mig samme. Flere Landraader vare her kun en kort Tid, de søgte ikke mig, og jeg ikke dem, dog veed jeg, at der blev indberettet om mig. Som man sagde ved v. Bitters Foranstaltning kom nu Landraad Magdeburg til Als.

22) 1873. Om den af ham indslaaede skarpere Kurs, en »Köllerpolitik før Köller« omend i adskillig mindre Format jfr. min »Nordslesvig $1864-1909 \ll$, S. 85 ff.

23) 1874. Han efterfulgtes af $v$. Saldern, medens den nedenfor nævnte Magdeburg var Landraad 1876-79. Jfr. -Nordslesvig*, S. 88 og 101. 
Han var en ganske ung Mand, der nyelig havde taget den saakaldte Referendarexamen i Berlin, da Krigen med Frankrig udbrød, eller maaskee under denne, og strax havde erholdt Ansættelse i Metz, hvorfra han blev forsat hertil. Han var en født Nassauer, og hans Hiem lige saa godt annecteret, som saa mange andre Lande, hans Fyrste lige saa godt afsat, som saa mange andre Fyrster; men han havde stortydske Sympathier og var aabenbart kaldet hertil for at virke i stortydsk Interesse, navnlig modvirke den $i$ det nordlige Slesvig herskende Danskhed. Dansk kunde han ikke, men var iøvrigt en meget fiin og dannet, vist ogsaa retsindig, samt meget dygtig Mand. Han havde læst den i 1848 i Nottmark suspenderede Pastor Petersens "Erlebnisse", men som det syntes, om min Person ikke dannet sig det Billede, som Pastor Petersen tilsigtede. Han var aabenbart i tydsk Retning, hvad Finsen, tidligere Borgmester i Sønderborg, derpaa Landshøvding paa Island, havde været i dansk Retning, kun aldeles høflig og langt fra i Overmod at fornærme nogen. Vort Forhold var [i] det ydre venskabelig. Jeg varetog mit Embede, udtalte i private Kredse min Mening om de nye Foranstaltninger, som jeg i den danske Tid havde gjort, men indlod mig aldeles ikke i Nogetsomhelst, der stod i Forbindelse med Politiken. En stor Behagelighed for mig var det, at min Ven fra Barndomsdage Fangel var min Provst. Da der næppe var Nogen, der kjendte den danske Kirkeret og de her gjældende kirkelige Forhold, og disse kom til Forhandling, følte jeg mig opfordret til at meddele saavel Consistoriet i Kiel som Kirkevisitatoriet, da navnlig Landraadsamtet, en udførligere Fremstilling af Øens kirkelige Forhold i politisk og kirkelig Henseende ...

B.

Redaktion I. S. 301-07, der slutter sig til II's Skildring af Præstejubilæet (Udg. S. 203-04).

.... I ethvert Tilfælde troede jeg ikke at kunne undslaae mig for lige saavel $i$ det Ydre, som $i$ det Indre at vise, at jeg 
paaskjønnede den mig viste Opmærksomhed. Jeg inviterede derfor Landraaden med Præsterne samt Menighedens Deputation, en valgt Mand af hver $\mathrm{By}_{\mathrm{y}}$ og Degnen Matzen. Det var ikke en let Sag ved denne Leilighed at udbringe Kejserens Skaal uden at fornægte sig selv og sin Fortid samt i Overværelse af et saa blandet tildeels officielt Selskab, en preussisk Landraad, gamle Slesvigholstenere, ivrige Danske. Skjøndt Nogle kun forstod lidt Tydsk, maatte den udbringes paa Tydsk. Det vil maaskee ikke være uden Interesse at hidsætte denne, skiøndt der kun kan indestaaes for Tanken, ikke for det enkelte Ord:

Før jeg beder Dem drikke et Glas paa Hs. Majestæt Kejserens og Kongens Vel, vilde jeg gærne fremstille mit Standpunkt under de mange indviklede Forhold, under hvilke jeg har levet. Jeg ved, at D'Hrr. har hørt og læst mange forskellige Bedømmelser af mig. Jeg er bleven skildret som en sort Sjæl, og Gud ved hvad ellers, og gamle Venner har ikke turdet besøge et saadant Menneske. Der er bleven skrevet en hel Bog, i hvilken jeg spiller en Hovedrolle. ${ }^{24}$ ) Gud har nu givet mig den Naade ikke at lade min Sindsro forstyrre af sligt. Paa den anden Side har jeg erfaret mange Beviser paa Kærlighed, og at ikke alle bedømmer mig paa denne Maade, viser Tilstedeværelsen af saa mange skattede Embedsbrødre og Venner og fremforalt den mig i Dag af Hs. Majestæet Kejseren og Kongen tildelte Udmærkelse. Jeg beder Dem derfor drikke et Glas paa hans Velgaaende, men vilde dog gærne forst nærmere fremstille det Standpunkt, jeg har indtaget i hele mit offentlige Liv. I Bedømmelsen af alle ydre Fænomener har jeg bestandig $i$ de ydre Fænomener kun kunnet se et Middel til at naa et aandeligt Formaal. I enhver religiøs Doctrin, enhver religiøs Institution, enhver religiøs Handling har jeg kun kunnet se et Middel til i Mennesket at vække en hellig Aand, det vil sige en Aand, der skyer det Onde og vækker Kærligheden i Menne-

24) Petersens ovenfor S. 15 omtalte *Erlebnisse. 
sket. Men her er nu mindre Tale om religiøse Anskuelser end om det Standpunkt, jeg har indtaget overfor de politiske Konstellationer. Men jeg har ogsaa her den samme Anskuelse. Jeg har kun kunnet bedømme alle Fænomener $\mathbf{i}$ det borgerlige Liv ud fra det Synspunkt, om hvorvidt de tjente til en virksom og heldbringende Samvirken af Menneskene. Den saa ofte omtalte „Frihed og Lighed“ har jeg stadig kun kunnet opfatte som en Frase. Thi Frihed til det gode er ogsaa Frihed til det onde, og $i$ et Samfund kan ingen have Frihed til at gøre, hvad han vil. Ligeledes maa der $i$ et Samfund være en Regering og kan ikke være Lighed. Lighed er en Uting. Jeg har derfor aldrig, selv ikke i mine yngre Aar, sværmet for en saakaldt fri Forfatning. Et Folks Lykke er ikke afhængig af Statsformen, men af Folkets Aand. Naar der er Aand i et Folk, kan der herske den storste Frihed og den største Lykke under den mest uindskrænkede Absolutisme. Den danske Konge Frederik VI var saa uindskrænket en Hersker, som det er muligt. Hans Vilje var Lov og kunde gøre enhver et Hoved kortere. Men hvis han vilkaarlig havde gjort det én Gang, to Gange, tre Gange, saa vilde den moralske Folelse have rejst sig og styrtet ham fra Tronen. Det Folk, der lader sig tyrannisere, kan kun regeres ved Tyranni og fortjener at blive tyranniseret. Paa den anden Side kan den frieste Statsform ofte være forbundet med det største Tyranni. Man tænke kun paa Frankrig 1793 og 1871. Jeg kan derfor ikke se anderledes paa Statsformerne, end at den bedste Statsform er den, under hvilken Folket befinder sig bedst, og det afhænger af Folkekarakteren og Omstændighederne. Andet er der ikke at sige om den Ting. I Tredverne, da jeg var en ung Mand, drøftede jeg dette med en Ven [og Slægtning] $]^{25}$ ) der var endnu yngre [og nu bor i Tyskland som Professor i Nationaløkonomi $]^{25}$ ). Efter Revolutionen i Paris 1830 sværmede næsten hele Europa for saakaldte

${ }^{25}$ ) De indklamrede Ord er overstreget i Manuskriptet. Der sigtes фjensynlig til den bekendte Agrarhistoriker Georg Hansen, der var hans Fætter. 
liberale Forfatninger, og min Ven var meget indtaget $i$ dem. Jeg henviste til Grækenlands og Roms Historie ja selv til Frankrigs efter $1830 \mathrm{og}$ gjorde opmærksom paa, at 100 Mennesker ganske vist besidder mere Intelligens og Erfaring end ét, men at med 100 Mennesker er ogsaa 100 private Intereser og mange Lidenskaber forbundet, hvortil desuden endnu kommer, at af 100 udøver kun 3 til 4 nogen Autoritet. I min senere Correspondance har jeg stadig gentaget, at jeg endnu stadig har denne Opfattelse. Paa samme Tid [altsaa vel i Tredverne] skrev jeg $i$ et herværende tysk Blad en Artikel „Das Steuerbewilligungsrecht und unsere Verhältnisse “, ${ }^{28}$ ) hvori jeg søgte at gøre gældende, at Skattebevilligelsesret kunde være god nok, men der var andet at ordne, som vilde være vigtigere. Artiklen blev beslaglagt et Tidernes Tegn! Jeg har troet at turde forudiskikke dette for at forklare mit Forhold til vort eget Virvar. Men jeg beder Dem om i mine Bemærkninger ikke at se nogen politisk Diskussion, men kun mit Syn paa Sagen. Det var min Opfattelse, at Danske og Tyske skulde være bleven sammen og forligtes indbyrdes. Jeg var derfor ligesaalidt en Ven af Holstens Adskillelse fra Slesvig som af Hertugdømmernes Adskillelse fra Danmark. Da nu Revolutionen i Paris 1848 havde gjort Folk gale, og der i Martsdagene allesteder var „Revolution og Rebellion", gjorde jeg den daværende Kancellipræsident i København, Bardenfleth, min Opvartning, netop da Folk forsamlede sig i Casino ligeved hans Bolig for at proklamere Slesvigs Adskillelse fra Holsten. Jeg sagde til ham "de Folk er gale“27). Han saa paa mig uden at mæle et Ord; jeg gjorde Audiensen kort og anbefalede mig. Overalt forsamlede sig nu de politiske Skræddere for at sy nye Uniformer til Staterne. Legemernes Sundhed brød de politiske Modejunkre sig ikke om. Saaledes var det ogsaa hos os. Paa given Foranledning gjorde jeg 26. Marts 1849 i en Skrivelse til Ministeriet mit ovenfor fremstil-

28) Jfr. Udg. S. 77-78.

27) Jfr. S. 11. Eftersætningen, Det er en ligesaa stor Separatisme som den anden « [den slesvigholstenske], har Bispen aabenbart ikke fundet det opportunt at medtage! 
lede Syn paa Statformerne gældende og fraraadede i bestemte Udtryk at fortsætte, spaaede ondt deraf. Naturligvis uden Held. Under Krigsurolighederne stod jeg paa Regeringens Side uden at kunne stemme overens med Regeringen $i$ de interne politiske Bestræbelser. Hvad jeg har anført vil forklare mit Standpunkt $\mathrm{i}$ begge Retninger. Jeg blev stillet ved Siden af to 'holstenske Hædersmænd, Grev Carl Moltke, holstensk Godsejer, og Dithmarskeren Konferensraad Johannsen, mangeaarig Amtmand i Haderslev. ${ }^{28}$ ) Med dem begge stemte jeg fuldstændig overens. Vi var liberale, d. v. s. saa vidt man skulde være human, og nationale, forsaavidt som vi anerkendte Nationaliteten som et Element i Staten, der dog ikke bør være dominerende, men ellers absolut ikke national-liberale, som Politikerne kaldte og kalder det. Da Grev Moltke gik sin Vej, levede jeg i den bedste Overenstemmelse med Konferensraad Johannsen. Vi tog ingen Notits af patriotiske Taler, thi patriotiske Taler og patriotisk Sindelag er to meget forskellige Ting. Bag Talerne skjuler sig ofte private Interesser og ikke sjælden Privathad. Mundtlige Angiverier fandt døve Ører, og skriftlige uden Kendsgærninger blev lagt ad acta. Da Konferensraad Johannsen gik tilbage til Haderslev, søgte jeg at blive fritaget for den civile Forvaltning, hvad der ogsaa lykkedes mig, om end først efter gentagne Anmodninger. $\mathrm{Nu}$ kunde jeg helt hellige mig til mit biskoppelige Embede. Forholdene var her abnorme. Den danske Kirkeoverhøjhed udelukkede Hertugdømmernes Forvaltning og Love, men paa den anden Side ansaa jeg den danske Rigsdag som incompetent til at give Love for os. Jeg opponerede derfor mod Losning af Sognebaandet, mod Konfirmation to Gange om Aaret, mod Skoleloven af 1856, samt mod at Kirkemidlerne opførtes paa Finansbudgettet. Efter lange Forhandlinger blev min Opposition godkendt som berettiget. Det er imidlertid klart, at en saadan Tilstand ikke kunde være holdbar hverken i Almindelighed eller her. Jeg sagde

${ }^{23}$ ) Som Medlem af den saak. sImmediatkommission *. Jfr. S. 15. 
derfor ogsaa Regeringen saa ofte mit Embede gav Anledning dertil, og enhver, der vilde høre mig, at en Forandring var nødvendig. Jeg haabede imidlertid stadig paa en fredelig Løsning, men tog Fejl paa dette Punkt. Da nu Katastrofen kom fra Berlin, ansaa jeg det for min Pligt at acceptere de givne Forhold, som jeg hverken havde fremkaldt eller kunde have hindret, og opfordrede $i$ et Cirkulære Gejstligheden til at gøre det samme. Friherre v. Zedlitz lod Cirkulæret trykke som Tegn paa, at han anerkendte dets Indhold. Med Hr. v. Zedlitz havde jeg en Samtale og senere en længere Brevveksling. Jeg har ikke færre end 8 Breve fra ham. Han anerkendte fuldstændig min Holdning, og jeg kan ikke lade være med at erklære, at jeg i det hele er bleven behandlet over al Forventning af ham. Det var en Følge af hele min Holdning, at jeg ikke tilfredsstillede noget Parti. I Rigsdagen i København erklærede man, at man intet skyldte en Mand, der havde aflagt Troskabsed til Kongen af Prøjsen. Her har man forsynet Regeringen med Masser af Akter om min Ringhed. Jeg under de Herrer den Fornøjelse og Papirmøllerne den Fortjeneste, thi ingen Regering tager Notits af Angivelser uden Kendsgerninger. Jeg har stadig stræbt efter at være en ærlig Mand og troer at have tjent Kongen af Danmark som en ærlig Mand, selv naar jeg har været i Opposition til Regeringens Forholdsregler. Overfor Prøjsen ved jeg ikke at have haft andre Fortjenester end enhver ærlig Mand, der ærlig stræber efter at opfylde de Forpligtelser, han har paataget sig. Naar derfor Hs. Majestæt Kongen og Kejseren har ladet en saa høj Udmærkelse blive mig til Del, saa kan jeg deri kun se en Anerkendelse af en ærlig Bestræbelse uden Hensyn til de Forhold, under hvilke den er udvist. En saadan Udmærkelse fortjener fra vor Side den største Anerkendelse, og jeg beder derfor det ærede Selskab drikke et Glas paa Hs. Majestæt Kongens og Kejserens Velgaaende, at han vedblivende maa herske sig selv til Glæde og os til Gavn. 